\title{
Exploring the Basis of Disease
}

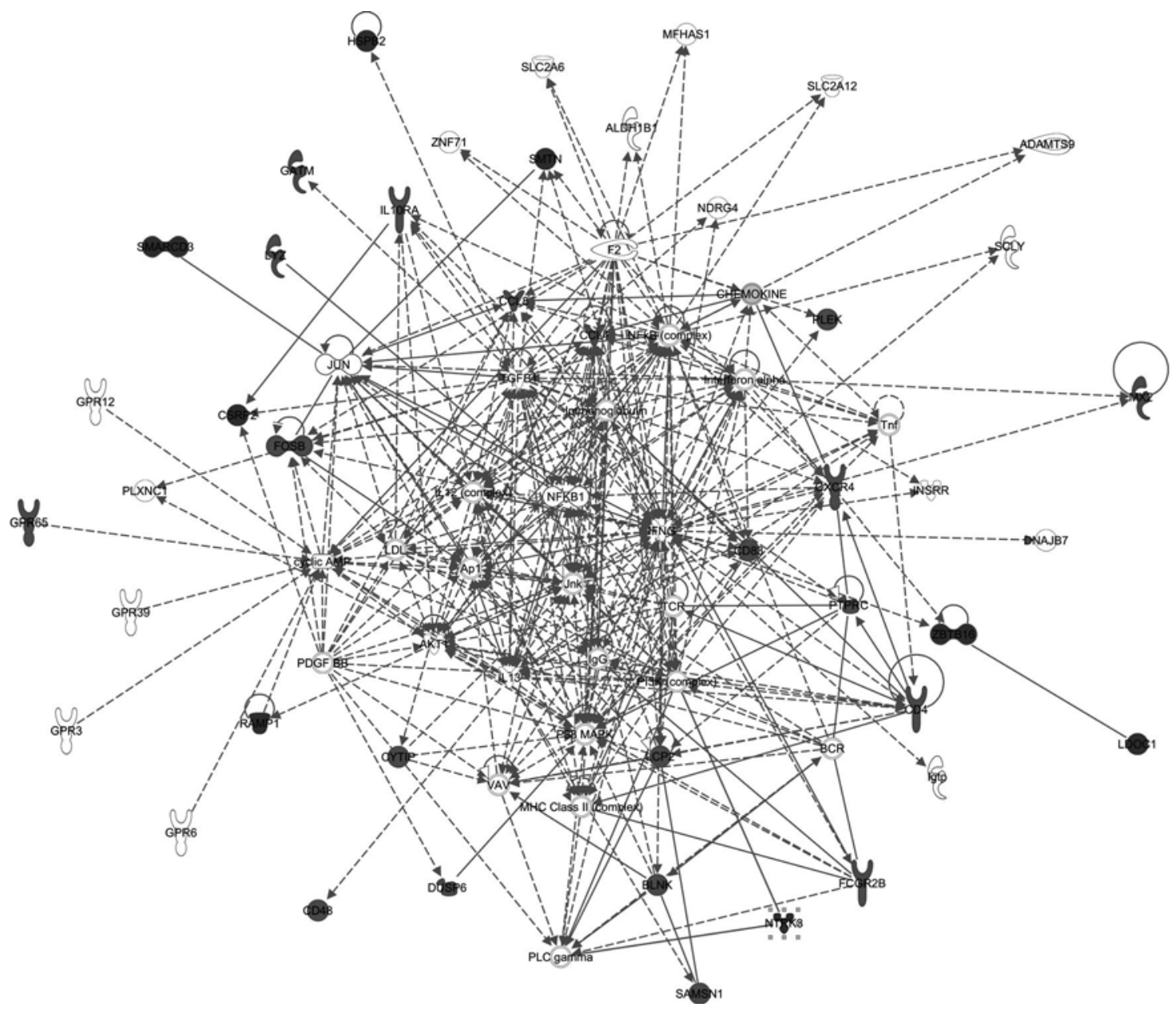

S. Karger

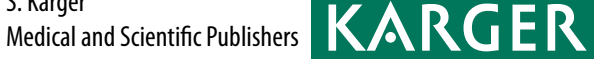
Basel · Freiburg · Paris .

London - New York .

New Delhi · Bangkok · Beijing ·

Tokyo - Kuala Lumpur ·

Singapore - Sydney 


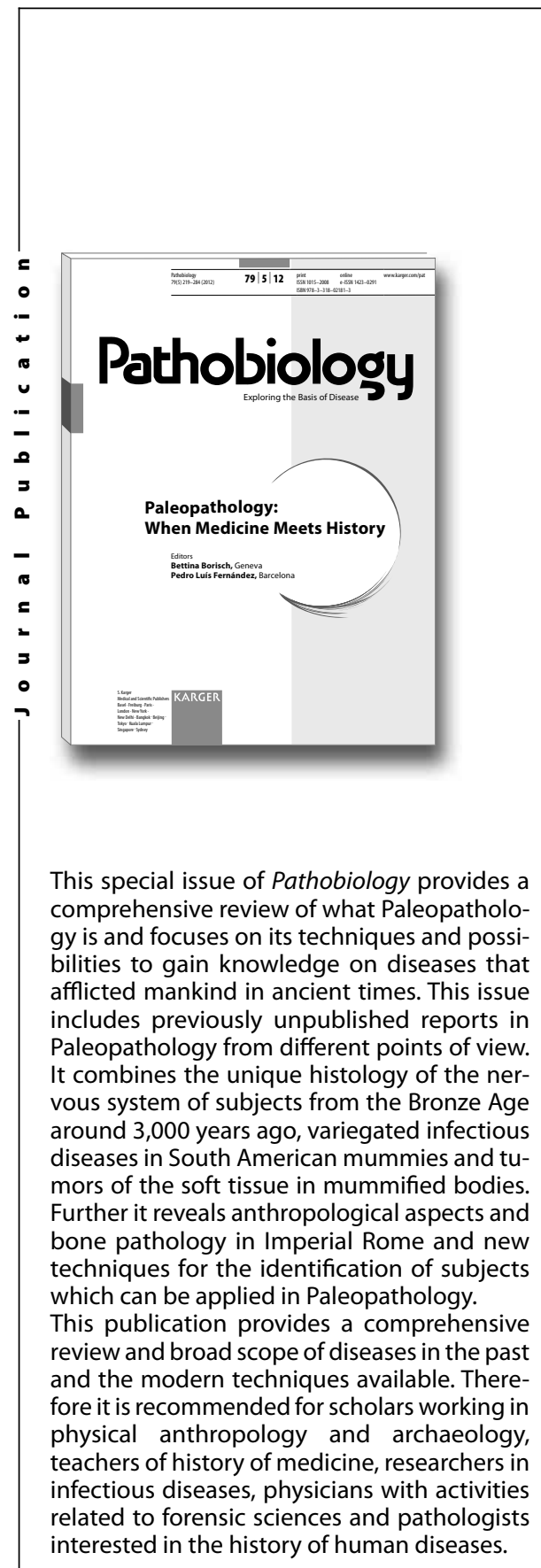

\title{
A wide glance at diseases in ancient times \\ and new technologies for its study
}

\section{Paleopathology: When Medicine Meets History}

\author{
Editors \\ Bettina Borisch \\ Pedro L. Fernández
}

\section{Contents}

Palaeopathology: The Study of Disease in the Past: Fernández, P.L.

Genetic Identification of Missing Persons: DNA Analysis of Human Remains and Compromised Samples:

Alvarez-Cubero, M.J.; Saiz, M.;

Martinez-Gonzalez, L.J.; Alvarez, J.C.; Eisenberg, A.J.; Budowle, B.; Lorente, J.A.

A Paleoneurohistological Study of 3,000-Year-Old Mummified Brain Tissue from the Mediterranean Bronze Age: Prats-Muñoz, G.; Malgosa, A.; Armentano, N.; Galtés, l.; Esteban, J.; Bombi, J.A.; Tortosa, M.; Fernández, E.; Jordana, X.; Isidro, A.; Fullola, J.M.; Petit, M.À.; Guerrero, V.M.; Calvo, M.; Fernández, P.L.
Paleopathology in South American Mummies: A Review and New Findings: Gerszten, E.; Allison, M.J.; Maguire, B.

Soft Tissue Tumors in Palaeopathology: A Review: Fornaciari, G.; Giuffra, $\boldsymbol{v}$.

Palaeopathology of Human Remains from the Roman Imperial Age: Minozzi, S.; Catalano, P.; Caldarini, C.; Fornaciari, G.

\section{Paleopathology:}

\section{When Medicine Meets History}

Editors: Borisch, B. (Geneva); Fernández, P.L. (Barcelona) 66 p., 62 fig., 54 in color, 6 tab., soft cover, 2012

CHF 29.- / EUR 24.- / USD 34.00

Prices subject to change

EUR price for Germany, USD price for USA only

ISBN 978-3-318-02181-3

e-ISBN 978-3-318-02182-2

Special Topic Issue

Pathobiology

Vol. 79, No. 5 (2012)

Included in subscription

\section{Please send: __ copy/ies}

Postage and handling free with prepayment

E Payment:

- Please charge to my credit card

- $\square$ American Express $\square$ Diners

ᄂ $\square$ MasterCard $\square$ Visa

- Card No.

व

ర Exp. date:

- CVV/CVC

( 3 digits in the signature field on the back of Visa and MasterCard)

$\square$ Check enclosed $\square$ Please bill me

Orders may be placed with any bookshop, subscription agency, directly with the publisher or through a Karger distributor.
Fax: +41 613061234

S. Karger AG, P.O. Box, CH-4009 Basel (Switzerland) E-Mail orders@karger.ch,www.karger.com

Name/Address: 


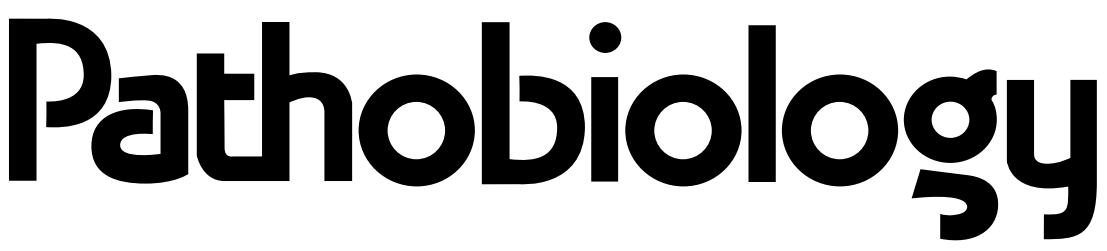

Founded 1938 as 'Schweizerische Zeitschrift für allgemeine Pathologie und Bakteriologie' by A. v. Albertini, A. Grumbach and H. Mooser, continued as 'Pathologia et Microbiologia' (1960-1975) and 'Experimental Cell Biology' (1976-1989); incorporating 'Pathology and Immunopathology Research', founded 1982 as 'Survey and Synthesis of Pathology Research' by J.M. Cruse and R.E. Lewis, continued as 'Pathobiology', edited by J.M. Cruse and R.E. Lewis (1990-1998) Continued by Ch. Wittekind (1999-2004)

\section{Editor-in-Chief}

B. Borisch, Geneva

\section{Regional Editor: Far East}

W. Yasui, Hiroshima

\section{Editorial Board}

H. Denk, Graz

P.L. Fernandez, Barcelona

A. Horii, Sendai

C. Jackson, Sydney

A. Janin, Paris

A. Katalinic, Lübeck

C.J. Kirkpatrick, Mainz

S. Kumar, Manchester

J.A. Kummer, Utrecht

H.-A. Lehr, Lausanne

A. Perren, Bern
S.A. Pileri, Bologna

S. Pinder, London

M. Reymond, Herne

P. Suat-Cheng, Kuala Lumpur

A. Tannapfel, Bochum

J. Van der Walt, London

M. Werner, Freiburg

H-K. Yang, Seoul

K. Zatloukal, Graz

W.L. Zhao, Shanghai
Printed in Switzerland on acid-free and non-aging paper (ISO 9706) by Reinhardt Druck, Basel
Appears bimonthly: 1 volume per year (6 issues) 


\section{Aims and Scope}

Pathobiology offers a valuable forum for high quality original research into the pathophysiological and pathogenetic mechanisms underlying human disease. Aiming to serve as a bridge between basic biomedical research and clinical medicine, the journal welcomes articles from scientific areas such as pathology, oncology, anatomy, virology, internal medicine, surgery, cell and molecular biology, and immunology. Published bimonthly, the journal features original research papers, reviews, short communications and editorials. Papers highlighting the clinical relevance of pathological data are encouraged. A special section will be devoted to reports on methodological improvements, and in the 'International Forum' section current or controversial issues will be discussed by specialists in the field.

\section{Submission}

Manuscripts should be submitted using the online submission website at:

\section{www.karger.com/pat}

Should you experience any problems with your submission, please contact:

\section{Laetitia.Bourquin@unige.ch \\ Prof. Dr. Bettina Borisch \\ Centre Médical Universitaire \\ 1 , rue Michel-Servet \\ $\mathrm{CH}-1211$ Genève 4 (Switzerland)}

\section{Conditions}

Manuscripts must be written in English, and are all subject to peer review. Manuscripts are received with the explicit understanding that they are not submitted for simultaneous consideration by any other publication. Submission of an article for publication implies the transfer of the copyright from the author to the publisher upon acceptance. Accepted papers become the permanent property of 'Pathobiology' and may not be reproduced by any means, in whole or in part, without the written consent of the publisher. It is the author's responsibility to obtain permission to reproduce illustrations, tables, etc. from other publications. For papers that are accepted for publication, manuscript copies and illustrations will not be returned to the authors. For papers that are rejected, only the set of original figures will be returned.

\section{Arrangement}

Title page: The first page of each paper should indicate the title, the authors' names, the institute where the work was conducted, and a short title for use as running head.

Full address: The exact postal address of the corresponding author complete with postal code must be given at the bottom of the title page. Please also supply phone and fax numbers, as well as e-mail address.

Key words: Please supply 3-10 key words in English that reflect the content of the paper.

Abstract: Each paper needs an abstract of up to 200 words structured with subheadings as follows: Objective(s), Methods, Results, Conclusion(s).

Footnotes: Avoid footnotes. When essential, they are numbered consecutively and typed at the foot of the appropriate page.

Tables and illustrations: Tables and illustrations (both numbered in Arabic numerals) should be prepared on separate sheets. Tables require a heading and figures a legend, also prepared on a separate sheet. For the reproduction of illustrations, only good drawings and origina photographs can be accepted; negatives or photocopies cannot be used. Due to technical reasons, figures with a screen background should not be submitted. When possible, group several illustrations on one block for reproduction (max. size $180 \times 223 \mathrm{~mm}$ ) or provide crop marks. On the back of each illustration, indicate its number, the author's name, and 'top' with a soft pencil. Electronically submitted b/w half-tone and color illustrations must have a final resolution of $300 \mathrm{dpi}$ after scaling, line drawings one of 800-1200 dpi.

Color illustrations

Online edition: Color illustrations are reproduced free of charge. In the print version, the illustrations are reproduced in black and white. Please avoid referring to the colors in the text and figure legends.

Print edition: Up to 6 color illustrations per page can be integrated within the text at CHF 800.- per page.

\section{References}

In the text identify references by Arabic numerals [in square brackets]. Material submitted for publication but not yet accepted should be noted as 'unpublished data' and not be included in the reference list. The list of references should include only those publications which are cited in the text. Do not alphabetize; number references in the order in which they are first mentioned in the text. The surnames of the authors followed by initials should be given. There should be no punctuation other than a comma to separate the authors. Preferably, please cite all authors. Abbreviate journal names according to the Index Medicus system. (Also see International Committee of Medical Journal Editors: Uniform requirements for manuscripts submitted to biomedical journals. N Engl J Med 1997;336:309-315.)

\section{Examples}

(a) Papers published in periodicals: Sun J, Koto H, Chung $\mathrm{KF}$ : Interaction of ozone and allergen challenges on bronchial responsiveness and inflammation in sensitised guinea pigs. Int Arch Allergy Immunol 1997;112:191195.

\section{(b) Papers published only with DOI numbers:}

Theoharides TC, Boucher W, Spear K: Serum interleukin-6 reflects disease severity and osteoporosis in mastocytosis patients. Int Arch Allergy Immunol DOI: $10.1159 / 000063858$.

(c) Monographs: Matthews DE, Farewell VT: Using and Understanding Medical Statistics, ed 3, revised. Basel, Karger, 1996.

(d) Edited books: Parren PWHI, Burton DR: Antibodies against HIV-1 from phage display libraries: Mapping of an immune response and progress towards antiviral immunotherapy; in Capra JD (ed): Antibody Engineering. Chem Immunol. Basel, Karger, 1997, vol 65, pp 18-56.

Reference Management Software: Use of EndNote is recommended for easy management and formatting of citations and reference lists.

\section{Digital Object Identifier (DOI)}

S. Karger Publishers supports DOIs as unique identifiers for articles. A DOI number will be printed on the title page of each article. DOIs can be useful in the future for identifying and citing articles published online without volume or issue information. More information can be found at www.doi.org.

\section{Supplementary Material}

Supplementary material is restricted to additional data that are not necessary for the scientific integrity and conclusions of the paper. Please note that all supplementary files will undergo editorial review and should be submitted together with the original manuscript. The Editors reserve the right to limit the scope and length of the supplementary material. Supplementary material must meet production quality standards for Web publication without the need for any modification or editing. In general, supplementary files should not exceed $10 \mathrm{MB}$ in size. All figures and tables should have titles and legends and all files should be supplied separately and named clearly. Acceptable files and formats are: Word or PDF files, Excel spreadsheets (only if the data cannot be converted properly to a PDF file), and video files (.mov, .avi, .mpeg).

\section{Author's Choice ${ }^{\mathrm{TM}}$}

Karger's Author's Choice ${ }^{\mathrm{TM}}$ service broadens the reach of your article and gives all users worldwide free and full access for reading, downloading and printing at www. Karger.com. The option is available for a one-time fee of CHF 3000.-, which is a permissible cost in grant allocation. More information can be found at www.karger. com/authors_choice.

\section{NIH-Funded Research}

The U.S. National Institutes of Health (NIH) mandates under the NIH Public Access Policy that final, peer-reviewed manuscripts appear in its digital database within 12 months of the official publication date. As a service to authors, Karger submits the final version of your article on your behalf to PubMed Central. For those selecting our premium Author's Choice ${ }^{\mathrm{TM}}$ service, we will send your article immediately upon publishing, accelerating the accessibility of your work without the usual embargo More details on NIH's Public Access Policy is available at http://publicaccess.nih.gov/policy.htm

\section{Self-Archiving}

Karger permits authors to archive their pre-prints (i.e. pre-refereeing) or post-prints (i.e. final draft post-refereeing) on their personal or institution's servers, provided the following conditions are met: Articles may not be used for commercial purposes, must be linked to the publisher's version, and must acknowledge the publisher's copyright. Authors selecting Karger's Author's Choice ${ }^{\mathrm{TM}}$ feature, however, are also permitted to archive the final, published version of their article, which includes copyediting and design improvements as well as citation links.

\section{Page Charges}

There is no page charge for papers of 7 or fewer printed pages (including tables, illustrations and references). Each additional complete or partial page is charged to the author at CHF 325.-. 3 manuscript pages (including tables, illustrations and references) are equal to approximately one printed page.

\section{Electronic Proofs}

Unless indicated otherwise, proofs will be e-mailed to the corresponding author.

\section{Reprints}

Order forms and a price list are sent with the proofs. Orders submitted after the issue is printed are subject to considerably higher prices.

\section{KARGER}

Fax +4161306 1234 E-Mail karger@karger.ch www.karger.com
(C) 2013 S. Karger AG, Basel 


\section{Pathobiology}

ISSN Print Edition: 1015-2008

ISSN Online Edition: 1423-0291

Journal Homepage: www.karger.com/pat

Publication Data: 'Pathobiology' is published 6 times a year. Volume 80 with 6 issues appears in 2013.

Copyright: (c) 2013 S. Karger AG, Basel (Switzerland). All rights reserved. No part of this publication may be translated into other languages, reproduced or utilized in any form or by any means, electronic or mechanical, including photocopying, recording, microcopying, or by any information storage and retrieval system, without permission in writing from the publisher or, in the case of photocopying, direct payment of a specified fee to the Copyright Clearance Center.

Disclaimer: The statements, opinions and data contained in this publication are solely those of the individual authors and contributors and not of the publisher and the editor(s). The appearance of advertisements in the journal is not a warranty, endorsement, or approval of the products or services advertised or of their effectiveness, quality or safety. The publisher and the editor(s) disclaim responsibility for any injury to persons or property resulting from any ideas, methods, instructions or products referred to in the content or advertisements.
Subscription Rates: Subscriptions run for a full calendar year. Prices are given per year. Personal subscription:

Print or Online

CHF 495.-

EUR 399.-

USD 490.00

Print+Online combined CHF 543.-

EUR 437.-

USD 538.00

postage and handling (added to print and print+online)

CHF 43.20 Europe, CHF 62.40 Overseas

EUR 33.60

USD 57.60

Institutional subscription

Print or Online

Print+Online combined

CHF 1978.

EUR 1595.-

CHF 2176.-

postage and handling (added to print and print+online)

CHF 54.- Europe, CHF 78.- Overseas

EUR 42.-

USD 72.00

Airmail surcharge: CHF 52.50 / USD 49.50

Discount subscription prices: Members of the AAI.
Back Volumes and Single Issues: Information on availability and prices of single print issues and print or electronic back volumes can be obtained from Customer Service at service@karger.ch.

Bibliographic Indices: This journal is regularly listed in bibliographic services, including Current Contents ${ }^{\circledR}$ and PubMed/MEDLINE.

Photocopying: This journal has been registered with the Copyright Clearance Center (CCC), as indicated by the code appearing on the first page of each article. For readers in the US, this code signals consent for copying of articles for personal or internal use, or for the personal or internal use of specific clients, provided that the stated fee is paid per copy directly to

Copyright Clearance Center Inc.

222 Rosewood Drive

Danvers, MA 01923 (USA)

A copy of the first page of the article must accompany payment. Consent does not extend to copying for general distribution, for promotion, for creating new works, or for resale. In these cases, specific written permission must be obtained from the copyright owner,

S. Karger AG, P.O. Box

CH-4009 Basel (Switzerland).
Subscription Orders:

Orders can be placed at agencies,

bookstores, directly with the Publisher

\section{S. Karger AG}

Medical and Scientific Publishers

P.O. Box

CH-4009 Basel

Switzerland

(for courier services only:

Allschwilerstrasse 10

CH-4055 Basel)

: +416130611 11

f: +41613061234

e: karger@karger.ch

w: www.karger.com or further Karger offices

or representatives:

Germany

S. Karger GmbH

Postfach

79095 Freiburg

Deutschland

(Hausadresse: Wilhelmstrasse 20A,

79098 Freiburg)

t: +49761452070

f: +497614520714

e: information@karger.de

w: www.karger.de

Japan

Karger Japan, Inc

Shiba Daimon Asahi Bldg. 2F

1-2-23 Shiba Daimon

Minato-ku

Tokyo 105-0012

Japan

t: +81364356242

f: +81364356244

e: publisher@karger.jp

w: www.karger.jp

Change of Address:

Both old and new address should be sent

to the subscription source.

USA

S. Karger Publishers, Inc.

26 West Avon Road

P.O. Box 529

Unionville, CT 06085

USA

Toll free: +18008285479

t: +18606757834

f: +18606757302

e: karger@snet.net

France

Librairie Médi-Sciences Sar

36, bd de Latour-Maubourg

75007 Paris

France

t: $+33(0) 145514258$

f: $+33(0) 145560780$

f: +33(0) 145560780

e: librairie@medi-sciences
w: www.medi-sciences.fr

Gulf Council Countries, Iran,

Middle East, North Africa, Turkey

Trans Middle East International

Distribution Co. Ltd. (KaSha)

168 B, King Abdullah the 2nd Street

Daboog Building 2nd Floor

Daboog Area

P.O. Box 2376

Amman 11953

Jordan

t: +962 65153467

f: +96265411336

e: info@kasha.cc

w: www.KaShaonline.com
South East Asia, China and Taiwan Karger Regional Office (Malaysia)

CEO Suite Kuala Lumpur

Quill 7, 27th Floor

Jalan Stesen Sentral 5

KL Sentral

Kuala Lumpur 50470

Malaysia

t: +60327766803

f: +60327766999

e: service@karger.cn; r.chew@karger.cn

Karger China

10th Floor, Twin Towers (East)

B12 Jianguomenwai Avenue

Beijing 100022

China

$\mathrm{t}:+861051235033$

f: +861051235122

e: service@karger.cn; r.chew@karger.cn

w: www.karger.cn

India, Bangladesh, Sri Lanka

Medscience India

Plot No. 17, Yusuf Sarai Market

B.L. Glass Building, 2nd Floor

Sri Aurobindo Marg

New Delhi 110016

India

t: +911146029633

f: +911146029634

c: +919891052128

e: medsci.india@gmail.com

\section{KARGER}

Fax +41 613061234

E-Mail karger@karger.ch

www.karger.com
(C) 2013 S. Karger AG, Basel

The Journal Home Page is available at:

www.karger.com/pat 


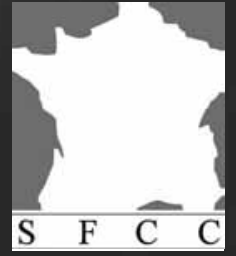

\section{www.cytologyperis2013.com}

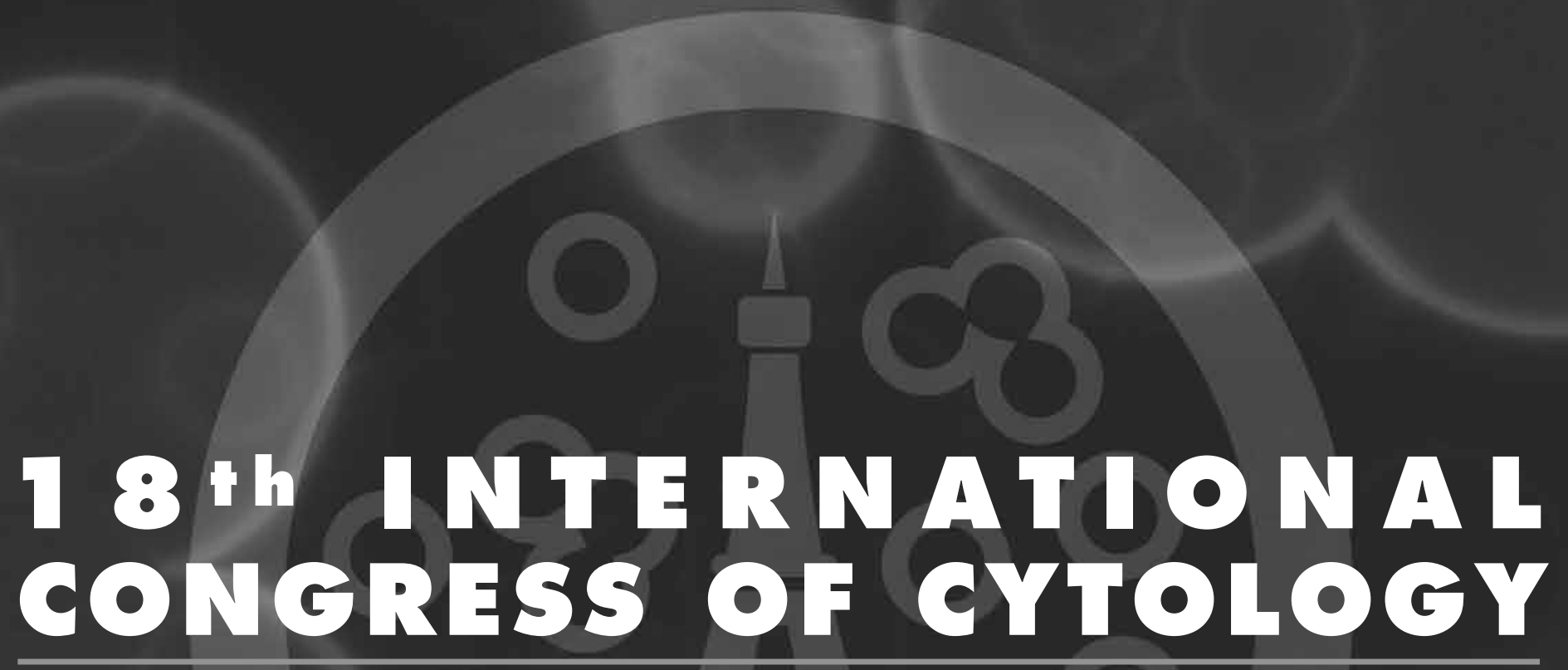

26-30 MAY 2013 - PALAIS DES CONGRİS, PARIS, FRANGE

Organised by the Société Française de Cytologie Clinique (SFCC) on behalf of the International Academy of Cytology (IAC)

Congress Office

CYTOLOGY 2013

$\mathrm{MCl}-24$ rue Chauchat

75009 Paris - France

Tel: $+33(0) 153858275$

Fax: $+33(0) 153858283$

Email: info@cyłologyparis2013.com

Web: www.cytologyparis2013.com 


\section{Contents}

See the journal website for contents

KARGER Basel $\bullet$ Freiburg $\cdot$ Paris $\bullet$ London $\bullet$ New York $\cdot$ New Delhi $•$ Bangkok Beijing $\cdot$ Tokyo $\cdot$ Kuala Lumpur $\cdot$ Singapore $\bullet$ Sydney 


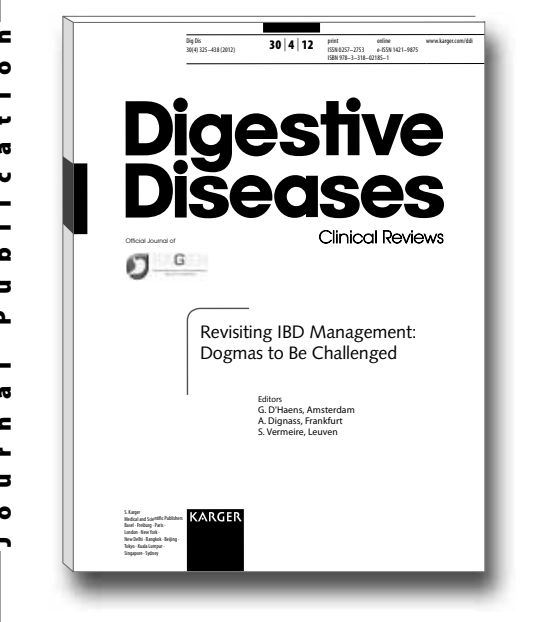

Contents

Introduction

Challenging Dogmas in IBD: D'Haens, G.

IBD Is a Disorder of Defective Autophagy and Innate Immunity

Evidence from Genetics for a Role of

Autophagy and Innate Immunity in IBD

Pathogenesis: Parkes, $\boldsymbol{M}$.

Commensal-Innate Immune Miscommunica-

tion in IBD Pathogenesis: Cario, $\boldsymbol{E}$.

Endoplasmic Reticulum Stress and

Inflammation: Adolph, T.-E.; Niederreiter, L.;

Blumberg, R.S.; Kaser, A.

No Bacteria, No IBD

Lessons from Diversion Studies and

Antibacterial Interventions: Flanagan, P.K.; Campbell, B.J.; Rhodes, J.M.

Bacteriology in the Etiopathogenesis of Pouchitis: Shen, $\boldsymbol{B}$.

The Role of Anti(myco)bacterial Interventions in the Management of IBD: Is There

Evidence at All? Pineton de Chambrun, G.P.; Torres, J.; Darfeuille-Michaud, A.;

Colombel, J.-F.

\section{Revisiting IBD Management: Dogmas to Be Challenged}

\author{
Falk Symposium 179 \\ Brussels, September-October 2011 \\ Editors \\ G. D’Haens \\ A. Dignass \\ S. Vermeire
}

\section{Steroids Are Useful for the}

\section{Management of IBD}

Second-Generation Corticosteroids for the Treatment of Crohn's Disease and Ulcerative Colitis: More Effective and Less Side Effects? De Cassan, C.; Fiorino, G.; Danese, $S$.

\section{Early and Late Crohn's Disease Are}

Distinct Entities

Epidemiology of the Transition from Early to Late Crohn's Disease: Louis, $\boldsymbol{E}$.

Markers That Differentiate Early from Late IBD: Huang, C.; Kugathasan, S.

Innovative Treatments Will Offer a Better

Outcome for Patients with IBD

Biologic Therapies: Lessons from Multiple Sclerosis: Ghosh, $\mathbf{S}$.

Current Status of Mesenchymal Stem Cell Therapy and Bone Marrow Transplantation in IBD: Ricart, $E$.

Reprogramming the Immune System in IBD: MacDonald, T.T.; Vossenkaemper, A.; Fantini, M.; Monteleone, $G$.
Patient-Tailored Therapies Are Superior to Algorithmic Approaches in IBD

How to Guide Therapeutic Decisions in a Patient-Tailored Approach to Treatment of IBD? Rutgeerts, $P$.

Treat the Patient or Treat the Disease? Hanauer, S.B.; Kirsner, J.B.

Immunosuppression Puts IBD Patients at

Risk for Severe Complications

Combined Immunosuppression Is More Dangerous than Monotherapy: What is Fact and What Is Fiction? Schölmerich, J.

Prevention and Management of Infectious Complications in IBD: Rahier, J.-F.

Immunosuppression-Related Lymphomas and Cancers in IBD: How Can They Be Prevented? Beaugerie, $\boldsymbol{L}$.

How to Manage IBD in Patients with Infections or Malignancies? Kohn, A.; Meddi, $P$.

Leaving the Dogmas Behind and Looking into the Future

Towards a Novel Molecular Classification of IBD: Vermeire, $\boldsymbol{s}$.

Towards a 'Cure' for IBD: Fiocchi, C.

www.karger.com/ddi

Revisiting IBD Management : $\longrightarrow$ Please send: __ copy/ies

Dogmas to Be Challenged

Falk Symposium 179, Brussels, September-October 2011 Editors: D'Haens, G. (Amsterdam); Dignass, A.

(Frankfurt); Vermeire, S. (Leuven)

114 p., 8 fig., 18 tab., soft cover, 2012

CHF 48.- / EUR 40.- / USD 56.00

Prices subject to change

EUR price for Germany, USD price for USA only

ISBN 978-3-318-02185-

Special Topic Issue:

Digestive Disease

Vol. 30, No. 4 (2012)

Included in subscription $\boldsymbol{\varepsilon}$ Payment:

Please charge to my credit card

- $\square$ American Express $\square$ Diners

ᄂ $\square$ MasterCard $\square$ Visa

- Card No.

๑

Exp. date:

- CVV/CVC

( 3 digits in the signature field on the back of Visa and MasterCard)

$\square$ Check enclosed $\quad \square$ Please bill me

Orders may be placed with any bookshop, subscription agency, directly with the publisher or through a Karger distributor
Fax: +41 613061234

S. Karger AG, P.O. Box, CH-4009 Basel (Switzerland)

E-Mail orders@karger.ch, www.karger.com

Name/Address: 


\section{Pathobiology}

Original Papers

1 Novel Pathways in the Pathobiology of Human Abdominal Aortic Aneurysms

Hinterseher, I. (Dresden/Danville, Pa.); Erdman, R.; Elmore, J.R.; Stahl, E.; Pahl, M.C.; Derr, K.; Golden, A. (Danville, Pa.); Lillvis, J.H. (Detroit, Mich.); Cindric, M.C.; Jackson, K.; Bowen, W.D.; Schworer, C.M.; Chernousov, M.A.; Franklin, D.P.; Gray, J.L.; Garvin, R.P. (Danville, Pa.); Gatalica, Z. (Phoenix, Ariz.); Carey, D.J.; Tromp, G.; Kuivaniemi, H. (Danville, Pa.)

11 Asymptomatic Abdominal Aortic Aneurysms Show Histological Signs of Progression: A Quantitative Histochemical Analysis

Eberlová, L.; Tonar, Z. (Pilsen); Witter, K. (Vienna); Křížková, V.; Nedorost, L.; Korabečná, M.; Tolinger, P.; Kočová, J.; Boudová, L.; Tř̌eška, V.; Houdek, K.; Moláček, J. (Pilsen); Vrzalová, J.; Pešta, M.; Topolčan, O. (Prague/Pilsen); Valenta, J. (Pilsen)

24 Increased Shedding of Microvesicles from Intimal Smooth Muscle Cells in Athero-Prone Areas of the Human Aorta: Implications for Understanding of the Predisease Stage

Bobryshev, Y.V. (Moscow/Kensington, N.S.W.); Killingsworth, M.C. (Liverpool, N.S.W.); Orekhov, A.N. (Moscow/Liverpool, N.S.W.)

32 Expression Profiling of Breast Tumors Based on Human Epidermal Growth Factor Receptor 2 Status Defines Migration-Related Genes

Cuadros, M.; Cano, C.; López, F.J.; López-Castro, R.; Concha, A. (Granada)

41 Metabolism-Related Proteins Are Differentially Expressed according to the Molecular Subtype of Invasive Breast Cancer Defined by Surrogate Immunohistochemistry

Choi, J. (Wonju); Jung, W.-H.; Koo, J.S. (Seoul) 